\title{
Politicians' priorities and the determinants of priorities in the Swedish social services
}

\author{
Marie Wörlén \\ Department of Social Work \\ Mid Sweden University \\ Email: marie.worlen@miun.se
}

\begin{abstract}
The setting of priorities is an integrated part of social-work politics in Sweden as well as internationally. This article explores Swedish social services and how politicians on the political boards wish to make priorities and what these priorities involve. The use of regression analyses also reveals which circumstances are of importance for allocative precedence and the impact different distributive principles have. It is hard to detect clear-cut patterns of circumstances that guide the judgements in any one direction. The results show that political affiliation overall is not a determining factor for attitudes towards how priorities are made. Another result is a manifest area bias, suggesting that respondents tend to see to the interests of their own professional domain, a result most visible among the politicians involved with Care for the Elderly and Disabled (CED). Yet, with regard to allocative principles, political colour seems to matter. Conservative politicians, as expected, agree with the principles of economy and of capacity to benefit, while the socialist block, less expectedly, seems to embrace the principle of deservingness.
\end{abstract}

Keywords: Priorities, Decision-making, social services, politicians

\section{Introduction}

In the wake of the financial crises of the 1990s and the late 2000s, the financial base for many Swedish welfare programmes had become somewhat eroded. Within the wide spectrum of services provided, the municipality-based social services represent a major component, including care of the elderly and the disabled, child welfare, social assistance, and treatment of substance abusers. Locally elected political bodies decide on the allocation of resources to various sectors and enjoy large discretion in this capacity, since the regulatory Social Services Act essentially provides a framework. 
A core element in all political activity is making priorities. Although individual political practice normally includes neither well articulated ranking lists nor explicit arguments for precedence, the shaping of political policy might concisely be defined, as Callahan (1987 p. 141) puts it, 'as a set of priorities of action and the resources oriented towards achieving a goal'. Hence, the necessity of setting priorities is neither a new feature of political life nor a result solely from a consequence of financial constraints. Scarce resources do, however, make the setting of priorities more challenging since they often involve cutbacks and less favourable conditions for certain areas or user groups.

The overall distribution of resources within the Swedish social services normally does not correspond to any single decision or easily identified political actor. In addition to formal political influence, allocative outcomes are also a result of how executives, administrators, and social workers implement political decisions. Political decisions regarding the total amount of resources distributed to various programmes or sectors are sometimes referred to as first-order decisions (Elster, 1992) or strategic decision-making. Second-order decisions refer to the allocation of given resources among potential users. In complex organizations, such as the social services, there are no clear-cut dividing lines between the two levels, which are intimately intertwined, but the range of political decisions and the scope of professional discretion vary from one area to another and between different municipalities (Thorslund, Bergmark, \& Parker, 1997). As a result, political accountability may sometimes seem somewhat hard to follow (Lewin, 2007; Thorslund et al., 1997).

The issues of 'who gets what?' and 'on what grounds?' evoke questions of basic values and how these are manifested in political and economic realities. The fundamental challenge of making choices in the social services lies in the balance between fulfilling public needs within given time limits and the budget provided. This is particularly emphasized in publicly funded organizations, which are expected to be permeated with fairness and equality (Martin, Giacomini, \& Singer, 2002; Temkin, 2003). This article will, on the basis of a study conducted in 2006-2007, analyse how politicians in a number of Swedish municipalities relate to decision-making involving priorities, what groups or activities they give precedence to, and how their orientation in this respect is shaped by values and personal-background factors. The focus here is not, however, actual priorities, but the politician's attitudes towards priorities.

\section{Priorities in the political sphere}

When making priorities in the social services, the decision-maker faces the task of putting one group or person ahead of others, that is setting some interests aside in order to give precedence to others (Callahan, 1987; Calltorp, 1989). This is a well established ingredient in political life as well as in professional practice. Political priorities have a direct bearing on micro-level decisions since they provide the financial and regulatory framework for the individual case (Björk \& Rosén, 1993; Lammintakanen \& Kinnunen, 2004). It is, however, an open question to what extent an allocative profile in a municipality can be regarded as a reflection of political will and of values attached to certain ideological positions (Lammintakanen \& Kinnunen, 2004).

The allocation of resources in the social services is a multifaceted policy operation (Karski \& Barth, 2000) that has need as an essential factor, where need is not only the rationale for the sector in itself but also constitutes the cornerstone of the Social Services Act. Different actors hold varied and often 
conflicting views on what constitutes a true or urgent need (Lister, 2010). Hence, the values and beliefs of political boards, clients, managers, and social workers can have an impact on how politicians make their decisions (Reilly, 1994). Everyday politics is then not only a trade-off between political parties or the implementation of political programmes, but to a large extent also an internal organizational process where numerous interests are involved (Greener \& Powell, 2003).

Four material principles of allocation may serve as representations of the different perspectives held by first-order actors: the principle of need, the principle of deservingness, the principle of economy, and the principle of capacity to benefit. As already established above, the principle of need stands out as central in social work, where it is prescribed, in short, that resources should be allocated on the basis of need and that motives for giving higher priority should be constituted on the basis of more severe and extensive needs. The concept of need is disputed, however. On the one hand, 'need' can be seen as equal to demand. On the other hand, 'need' can be described as a defined level (comparatively low) of welfare. When interpreting need as equal to demand, the social services are allowed to take a more passive stance, and to wait for initiatives or applications from claimants. With need defined as a low level of welfare follows the imperative to search out needy citizens and to establish outreach activities (Taylor \& Devine, 1994).

The principle of deservingness originates from the idea that it is morally wrong to recompense people who (knowingly or not) get themselves into trouble. This rests on the notion that negative incentive effects might be generated through generosity to undeserving groups, as it is likely that individuals will be less cautious about involving themselves in troubled situations if they know that compensation or treatment will be available (Dworkin, 1981). Historically, the principle of deservingness was a central one in Swedish poor-relief legislation (Wallentin, 1988). The principle of economy (or contribution), on the other hand, with its emphasis on the allocation of resources in accordance with how much the users contribute to their financing, can rather be seen as complementary to the other three. Support for a system where fees are paid by the applicants in order to benefit from services is a material expression of this principle, where the utilization of the principle may be regarded as an aspect of redistribution, since fees or co-payments normally only cover a certain amount of actual costs. The use of fees is repeatedly visualized by advocates of this principle as a needs test in itself, since it may serve to keep the less needy out (Bergmark, 1996).

The capacity to benefit, finally, is the principle whereby the clients who are most likely to improve their situation as a result of a social-services intervention should be given high priority (Hasenfeldt \& Steinmetz, 1981). The goal here is to target interventions in such a way that the highest average increase of welfare is achieved. With this follows the giving of high priority to clients with problems that match obtainable goals; to be exact, precedence is given to clients who have more solvable problems and equivalent lower priority is given to less solvable cases or to long-term cases.

From an ideal-type democratic perspective, politicians are expected to base their actions on ideologies and generally held values when fulfilling their promises to their voters. Besides following a particular political programme, this political accountability also involves openness to comments concerning how individuals actually are affected by the priorities made. However, strategic considerations are apt to complicate this view of local democracy, since organizational considerations, national politics, and short-term popular opinion 
may be involved in an unpredictable manner (Dierwechter \& Coffey, 2010; Lammintakanen \& Kinnunen, 2004). It has been argued that pragmatism is a more salient feature of local politics than ideology, and analyses show that political majority is a less significant factor for allocative policy than might be expected (Aronsson, 1999; Trydegård \& Thorslund 2001), in which case any underlying assumption that decisions and priorities are made with a rational and objective approach may be somewhat misleading (Lewin, 2007). Other factors to consider are organizational aspects, individual preferences, regional strategies, and the local parliamentary balance of power (Dierwechter \& Coffey, 2010; Lien \& Arnt Pettersen, 2004; Trydegård \& Thorslund, 2001). Priorities have further been shown to be affected by area bias, that is, a tendency to advocate or exercise priorities that serve the field one represents or the clients that are the target group for that area (Bergmark, 1995; Wörlén \& Bergmark, 2011). These tendencies to choose one's own area may originate from a self-serving bias, a better acquaintance with conditions within the field or from a fundamental dedication to the area.

To sum up, the setting of priorities is a process related to such organizational factors as the given municipality, fellow politicians, routines, and policies, as well as to personal factors. Nevertheless, decision-making is also about balancing personal preferences, professional opinions, and the influence of local guidelines and national legislation (Elster, 1992; Ham, 1997; Lewin, 2007).

\section{Methodology}

This study is based on a survey addressed to political decision-makers in six Swedish municipalities. In order to pick out more homogenous and manageable units to work with, a selection was first made of municipalities with a population ranging from 20000 to 65000 . This covered 95, or one-third of all municipalities in Sweden. Out of these 95 municipalities, six were then chosen on the basis of changes in expenditures in the period 2002-2004 for certain services (individual and family services, IFS) or cover ratios (care for the elderly and the disabled, CED). For the IFS, the focus was on child welfare and substance-abuse treatment. Two municipalities were chosen for their increase of resources in these areas, and another two for their decrease (picked from the top-two versus bottom-two deciles of municipalities with respect to increased or decreased resources). A similar selection was made in eldercare, on the basis of an increase or reduction in the relative proportion of the elderly who were provided home care or special housing during the same period. A reason for this was to see to what extent allocative trends were reflected in the attitudes and desired priorities of the studied politicians during that period. Finally, considerations of convenience were weighed in, on the basis of the distance to each municipality. Of the municipalities finally chosen, one (representing increased coverage rate in eldercare) that originally had agreed to participate subsequently withdrew. The municipality originally chosen for the pilot study - Östersund - was then added to make up the six. This municipality is situated in the same population range as the others and the only change made in the survey after the pilot was the removal of a number of questions. Table 1 presents the general characteristics of the selected municipalities. 
Table 1. Participating municipalities. Allocative trend, political majority, and population.

\begin{tabular}{|c|c|c|c|}
\hline Municipality & $\begin{array}{l}\text { Allocative } \\
\text { trend }^{\mathrm{a}}\end{array}$ & Political majority & Population \\
\hline Östersund & No specific ${ }^{*}$ & Socialist & 59000 \\
\hline Avesta & $\begin{array}{l}\text { Child welfare - } \\
\text { Eldercare }+^{* *}\end{array}$ & Conservative & 22000 \\
\hline Sandviken & Eldercare - & Socialist & 37000 \\
\hline Söderhamn & $\begin{array}{c}\text { Substance } \\
\text { abuse }+ \\
\text { Child welfare }+^{* *}\end{array}$ & Socialist & 26000 \\
\hline Sollefteå & Child welfare + & Socialist & 21000 \\
\hline Borlänge & $\begin{array}{c}\text { Substance } \\
\text { abuse - }\end{array}$ & Socialist & 47000 \\
\hline
\end{tabular}

a: - = decreased resources; + = increased resources; *selected for pilot; ** Not a criteria in the selection procedure

At the time of the study, the greater part of Swedish municipalities had a socialist majority. This was also the case for my selection, where only one of the six had a conservative majority. In relation to how the individual politicians responded to questions regarding allocative matters in their own municipality, one might expect those representing the minority to be less loyal with recent decisions and less in favour of existing practices of resource distribution. On the other hand, as Aronsson (1999) points out, local politics are often characterized by more pragmatism and less confrontation than are national politics and many solutions are reached by consensus.

Participating politicians who received the questionnaire were selected from a number of defined boards - the municipal, the CED [Care of the Elderly and Disabled], and the IFS [Individuals and Family Services] boards. The invitation to participate was put to 207 politicians, of whom 191 responded to the questionnaire. Most of the respondents answered the questionnaire during a regular board meeting, where the present researcher distributed it to them. Respondents who did not participate at the board meeting received a questionnaire through the mail. This generated a response rate of 92 per cent. Table 2 includes some facts on political affiliation, municipal board, and background. The socialist block comprises the Left Party, the Social Democrats, and the Green Party, and the conservative block the Centre Party, Liberal Party, Moderate Party, and Christian Democratic Party. There were a few smaller, local parties, but these are not included in the political blocks displayed here.

The socialist majority in the participating municipalities is well reflected in the distribution of the respondents, with more than 60 per cent belonging to this block. More than one-third were active in the municipal board, meaning that they - at least formally - were involved in more overarching allocative decisions and were supposed to be acquainted with the conditions in most areas. Respondents from the more specialized boards can be expected to have a more narrow scope of interest and knowledge and, hypothetically, a stronger area bias. In this respect the CED board group may be depicted as the most specialized, since it only included 'pure' CED members, while the IFS board group was here a merger of 'pure' IFS boards and other social boards with a somewhat wider scope. 
Table 2. Participants $(n=185-191)$.

\begin{tabular}{ll}
\hline Political block (per cent) & 61 \\
Socialist & 39 \\
Conservative & \\
Political board (per cent) & 37 \\
Municipal board & 30 \\
IFS board & 33 \\
CED board & \\
Gender (per cent) & 52 \\
Men & 48 \\
Women & $13(\mathrm{std}=10.4)$ \\
No of years in local politics (mean and std) & $53(\mathrm{std}=10.8)$ \\
Age (mean and std) &
\end{tabular}

Systematic comparisons between respondents from different political boards and different political blocks were carried out. Finally, a logistic regression was employed in order to estimate the relationships between desired priorities and certain characteristics, with other factors under control. The dependent variables in the regression models were the politicians' expressed priorities for groups that in a general manner may be targets for the social services (children, the elderly, the unemployed, and people with other social problems). The variable 'unemployed' was constructed out of one answer alternative to the question on what groups should be prioritized for investments for the future, while the other dependent variables were condensed from two answering alternatives. The variable 'Elderly' was constructed from 'elderly in general' and 'elderly over 80 years of age', 'Social problems' from 'young people with social problems (including their families)' and 'grown-up people with other social and psychological problems', and 'Children' from 'children and young people in general' and 'day-care children'. Throughout the regression models the dependent variables were made dichotomous. The independent variables were the factors that after initial testing on a bivariate level were related to the dependent variables. The choice of independent variables involved tests on a broad range of variables - demographic characteristics; personal factors such as education, age, years in municipal politics, part-time or full-time as politician, usage or experience of childcare or eldercare, or both, financial support, other individual and family services or care of the physically or mentally disabled; to what extent the politicians felt they needed to make priorities; in what areas cutbacks should be made; perceived problems of conflicting demands and insufficient resources; and principles of distribution - all with no significant causalities. All independent variables except the scales covering principles of distribution are, with reference to scale, categorical in the models. Tests of multicollinearity were also carried out. For a brief review of the independent variables, see Table 3. 
Table 3. Independent variables.

\begin{tabular}{|c|c|c|}
\hline Variable & Label & Comment \\
\hline Gender & Woman/Man & - \\
\hline $\begin{array}{l}\text { Children living in the } \\
\text { home }\end{array}$ & Yes/no & - \\
\hline Municipality & $\begin{array}{l}\text { Östersund, Avesta, Sandviken, } \\
\text { Söderhamn, Sollefteå, Borlänge }\end{array}$ & - \\
\hline Political block & Socialist/ Conservative & $\begin{array}{l}\text { Socialist block: Left, Social } \\
\text { Democratic and Green Party; } \\
\text { Conservative block: Liberal, } \\
\text { Moderate, Centre, and Christian } \\
\text { Democratic Party. }\end{array}$ \\
\hline Board at municipal level & $\begin{array}{l}\text { CED (Care of the Elderly and } \\
\text { Disabled), IFS (Individual and } \\
\text { Family Services), Municipal board }\end{array}$ & $\begin{array}{l}\text { The board composition differs } \\
\text { between the municipalities. In the } \\
\text { model I have screened out the 'pure' } \\
\text { boards in order to be able to make } \\
\text { regression models out of the different } \\
\text { areas. }\end{array}$ \\
\hline $\begin{array}{l}\text { Involvement in increase } \\
\text { of resources }\end{array}$ & $\begin{array}{l}\text { Eldercare, Care of the disabled, } \\
\text { Social Assistance, Child/Youth } \\
\text { welfare, Measures for substance } \\
\text { abusers }\end{array}$ & $\begin{array}{l}\text { The questionnaire had more items } \\
\text { covering these areas; however, this } \\
\text { number was cut down to fit the model. }\end{array}$ \\
\hline $\begin{array}{l}\text { Involvement in cutbacks } \\
\text { of resources }\end{array}$ & $\begin{array}{l}\text { Eldercare, Care of the disabled, } \\
\text { Social Assistance, Child/Youth } \\
\text { welfare, Measures for substance } \\
\text { abusers }\end{array}$ & $\begin{array}{l}\text { As above, these areas were more } \\
\text { numerous in the questionnaire, but } \\
\text { were reduced to fit the model. }\end{array}$ \\
\hline Allocative principle & $\begin{array}{l}\text { Deservingness, Need, Economy, } \\
\text { Capacity to benefit }\end{array}$ & $\begin{array}{l}\text { Scales based on three Likert-scale } \\
\text { items for each principle (added values } \\
\text { ranging from 3-12 = no support - total } \\
\text { support) }\end{array}$ \\
\hline
\end{tabular}

\section{Results}

One of the questions raised was how local politicians would like to see future priorities made. In the survey, the respondents were asked to say for what client group they wanted the social services to exert more effort in the future, explicitly, to give top priority in relation to the existing distribution of resources. As mentioned above, we may expect a certain bias in favour of users or problem areas connected with the political board where the respondents operate. The distribution yielded in Table 4 essentially confirms the existence of this kind of pattern, which is most visible for decision-makers within the CED board, which to a noticeably higher extent advocated increased priority for the elderly. Politicians in the IFS board could be expected to vote for any of the remaining groups, since all fall within the IFS domain. The table shows, however, that their area-specific bias only involves children, a preference they share with IFS professionals (Wörlén \& Bergmark, 2011). Children were also the group with the overall highest support. The least priority was given to the category 'people with social problems', which is a merger of various client groups and social difficulties where family or youth problems (including youth delinquency, domestic violence, etc.) dominate. The unemployed, a group that also falls within the IFS domain, attracted the least support and no specific priority from the IFS politicians. 
Table 4. Group given first priority by political board. Per cent.

\begin{tabular}{lcccc}
\hline & $\begin{array}{c}\text { Municipal } \\
\text { board } \\
(\mathbf{n = 7 0 )}\end{array}$ & $\begin{array}{c}\text { IFS board } \\
(\mathbf{n}=\mathbf{5 7})\end{array}$ & $\begin{array}{c}\text { CED board } \\
(\mathbf{n}=\mathbf{6 3})\end{array}$ & $\mathbf{p}^{*}$ \\
\hline The elderly & 14 & 10 & 43 & .000 \\
$\begin{array}{l}\text { People with social } \\
\text { problems }\end{array}$ & 23 & 25 & 11 & n.s. \\
Children & 37 & 49 & 24 & .015 \\
The unemployed & 16 & 14 & 14 & n.s \\
\hline
\end{tabular}

${ }^{*}$ Pearson $\mathrm{Chi}^{2}$

Table 5. Group given first priority by political block. Per cent

\begin{tabular}{lccl}
\hline & $\begin{array}{c}\text { Socialist } \\
(\mathbf{n}=\mathbf{1 1 4})\end{array}$ & $\begin{array}{c}\text { Conservative } \\
(\mathbf{n}=\mathbf{7 1})\end{array}$ & $\mathbf{p}^{*}$ \\
\hline The elderly & 21 & 23 & n.s. \\
$\begin{array}{l}\text { People with social } \\
\text { problems }\end{array}$ & 18 & 21 & n.s. \\
Children & 39 & 35 & n.s. \\
The unemployed & 14 & 16 & n.s. \\
\hline
\end{tabular}

${ }^{*}$ Pearson $\mathrm{Chi}^{2}$

Table 5 displays how politicians from the two political blocks wished to prioritize different groups, and the results do not conform to how we may expect political ideology ought to interact with these priorities. Thus, a hypothetical stance might be that conservatives may have a tendency to endorse the principle of deservingness - picking groups perceived to have no personal responsibility for their dependence - and thus advocate the needs of the elderly and of children to a higher extent than socialists would. No such pattern is visible, however. There are in fact no significant differences between the two political blocks at all. Whether this is a result of negligible ideological differences or a sign that the question does not capture existing dissimilarities in this respect is not possible to say. Local politics in Sweden is, as already established, frequently depicted as more pragmatic and less ideological than national politics (Aronsson, 1999).

Capturing the differences between the political blocks through their support for different allocative principles does, however, yield visible diversity related to political affiliation. In Table 6 we find that the conservatives embraced the principles of economy and of capacity to benefit to a larger extent than the socialists did. If we look at this from a common-sense view of conservative ideology these outcomes may be perceived as expected, especially for the principle of economy, which corresponds with notions of individual responsibility and decreased public financing. We may also, but less evidently, regard the principle of capacity to benefit as congruent with a conservative agenda since an increased focus on measurable outcomes could also be used as an argument for both decreased public involvement and less resources for clients with a long history within the social services. 
Table 6. Support for allocative principles by political block.

\begin{tabular}{|c|c|c|c|c|c|}
\hline \multirow[t]{2}{*}{ Principle } & \multicolumn{2}{|c|}{ Socialist (104-108) } & \multicolumn{2}{|c|}{ Conservative (67-70) } & \multirow[b]{2}{*}{$p^{a}$} \\
\hline & Mean & Std & Mean & Std & \\
\hline Deservingness & 8.87 & 1.83 & 6.66 & 2.21 & .000 \\
\hline Economy & 5.21 & 1.77 & 7.01 & 1.75 & .000 \\
\hline Need & 7.14 & 1.73 & 6.66 & 1.81 & .080 \\
\hline Capacity to benefit & 5.54 & 1.56 & 7.00 & 1.82 & .000 \\
\hline
\end{tabular}

a t-test

A somewhat less anticipated outcome is that the socialists expressed relatively greater support for the principle of deservingness. The notion of negative incentive effects as a result of generous benefits or the idea that it is morally incorrect to support people who are not immaculate victims of external circumstances is definitely more associated with a conservative discourse than a socialist one. The principle that created the least disagreement was the principle of need, which attracted fairly high support from both blocks.

Besides politicians' attitudes in relation to principles of distribution and desirable priorities, a majority have been involved in real allocative decisions that entailed cutbacks or added resources. In order to find out how these decisions were distributed over various areas we asked the respondents to report what they had been involved in during the past year. We also asked them to make distinctions between allocative decisions of a more general nature, those addressing an entire area, and those of a more detailed kind where specific activities were the object. Table 7 presents how the answers were distributed for the politicians on the different boards.

An expected result here was that the domains of the specialized boards would be reflected in these politicians' allocative decisions and that the members of the municipal board would display the most variety in this respect. In general, it seems that the board-specific pattern is more distinct for added resources than for cutbacks. Politicians active within a CED board were the ones most clearly concentrated on their own specific area. They also differed from the other boards by being involved in added resources and cutbacks to the same extent. One reason for this pattern might be that a rapidly ageing population makes this an area where demand has increased more than elsewhere and that this demand has to be met by the reallocation of resources. It is important, however, to be aware that Table 7 by no means offers an economic balance sheet of some sort or a manifestation of actual priorities, since we have no information on how big the added or decreased resources were in monetary terms, or how large the user groups were that were involved. The fact that cutbacks on the whole are less common than increases could also be an effect of decision-makers' reluctance to label their actions as 'rationing' or 'cutbacks' (Bergmark, 1997). Alternatively, it could also mean that the data had been collected in a period of improved finances. 
Table 7. Added resources and cutbacks by political board. Per cent.

\begin{tabular}{lcccc}
\hline & $\begin{array}{c}\text { Municipal } \\
\text { board (n=70) }\end{array}$ & $\begin{array}{c}\text { IFS board } \\
\text { (n=56) }\end{array}$ & $\begin{array}{c}\text { CED board } \\
\text { (n=61) }\end{array}$ & $\mathbf{p}^{*}$ \\
\hline Added resources to: & 33 & & & \\
Eldercare in general & 24 & 11 & 28 & .005 \\
Eldercare - certain services & 17 & 9 & 8 & .000 \\
Care of the disabled in general & 23 & 7 & 21 & n.s \\
Care of the disabled - certain services & 19 & 9 & 0 & .007 \\
Social assistance in general & 7 & 11 & 2 & n.s. \\
Social assistance - certain services & 33 & 27 & 8 & .003 \\
Child and youth welfare in general & 31 & 54 & 8 & .000 \\
Child and youth welfare - certain & & & & \\
services & 24 & 7 & 2 & .000 \\
Substance abuse care in general & 16 & 36 & 3 & .000 \\
Substance abuse care - certain services & 22.7 & 18.0 & 12.9 & \\
Mean & & & & \\
& 26 & 13 & 36 & .018 \\
Cutbacks of resources in: & 30 & 18 & 34 & n.s. \\
Eldercare in general & 13 & 2 & 13 & .063 \\
Eldercare - certain services & 6 & 2 & 18 & .005 \\
Care of the disabled in general & 10 & 11 & 4 & n.s \\
Care of the disabled - certain services & 9 & 9 & 10 & n.s \\
Social assistance in general & 7 & 11 & 2 & n.s \\
Social assistance - certain services & 7 & 13 & 5 & n.s \\
Child and youth welfare in general & & & & \\
Child and youth welfare - certain & 9 & 16 & 5 & n.s \\
services & 16 & 13 & 3 & .054 \\
Substance-abuse care in general & 13.3 & 8.8 & 13.0 & \\
Substance-abuse care - certain services & & & & \\
Mean & & & & \\
\hline
\end{tabular}

*Pearson $\mathrm{Chi}^{2}$

In Table 8 we return to desired priorities. This study took the analysis a step further by utilizing logistic regression models. Four different models were developed, each one with a group selected for priority as a dichotomous dependent variable, as shown in Tables 4 and 5 . Independent variables were selected in a two-step process, where variables unrelated on a bivariate level were rejected together with variables with a highly uneven distribution. (For further information on the variables included, see the method section above.) Factors such as family composition, age, time in local politics or personal experience of using certain social services did not establish any connections with desired priorities. 
Table 8. Groups picked to receive first priority. Logistic regression $(n=180)$

\begin{tabular}{|c|c|c|c|c|c|c|c|c|}
\hline & \multicolumn{2}{|c|}{$\begin{array}{c}\text { Elderly } \\
\mathrm{R}^{\mathrm{a}}=.359\end{array}$} & \multicolumn{2}{|c|}{$\begin{array}{c}\text { Social Problems } \\
\mathrm{R} 2=.321\end{array}$} & \multicolumn{2}{|c|}{$\begin{array}{l}\text { Children } \\
\text { R2=.282 } \\
\end{array}$} & \multicolumn{2}{|c|}{$\begin{array}{c}\text { Unemployed } \\
\text { R2=.303 }\end{array}$} \\
\hline & OR & $p^{b}$ & OR & $\mathbf{P}$ & OR & $p$ & OR & $p$ \\
\hline Gender: & & & & & & & & \\
\hline Male (ref) & 1.00 & & 1.00 & & 1.00 & & 1.00 & \\
\hline Female & 0.32 & .038 & 0.71 & .479 & 0.72 & .378 & 4.78 & .007 \\
\hline \multicolumn{9}{|l|}{ Children in family: } \\
\hline Yes (ref) & 1.00 & & 1.00 & & 1.00 & & 1.00 & \\
\hline No & 2.06 & .221 & 0.43 & .109 & 1.93 & .141 & 0.46 & .212 \\
\hline \multicolumn{9}{|l|}{ University education: } \\
\hline Yes (ref) & 1.00 & & 1.00 & & 1.00 & 1.00 & 1.00 & \\
\hline No & 0.43 & .642 & 1.25 & .655 & 0.82 & .622 & 2.05 & .212 \\
\hline \multicolumn{9}{|l|}{ Municipality: } \\
\hline Östersund (ref) & 1.00 & & 1.00 & & 1.00 & & 1.00 & \\
\hline Avesta & 2.29 & .465 & 65.41 & .018 & 0.19 & .049 & 0.34 & .414 \\
\hline Sandviken & 2.25 & .324 & 6.02 & .251 & 0.36 & .138 & 0.74 & .778 \\
\hline Söderhamn & 1.05 & .959 & 6.04 & .260 & 0.62 & .539 & 0.39 & .418 \\
\hline Sollefteå & 1.78 & .549 & 19.39 & .072 & 0.59 & .500 & 0.47 & .514 \\
\hline Borlänge & 0.97 & .975 & 19.22 & .069 & 0.23 & .047 & 1.71 & .595 \\
\hline \multicolumn{9}{|l|}{ Political block: } \\
\hline Socialist (ref) & 1.00 & & 1.00 & & 1.00 & & 1.00 & \\
\hline Conservative & 0.52 & .297 & 4.03 & .042 & 1.31 & .577 & 0.78 & .722 \\
\hline \multicolumn{9}{|l|}{$\begin{array}{l}\text { Board at municipal } \\
\text { level: }\end{array}$} \\
\hline CED (ref) & 1.00 & & 1.00 & & 1.00 & & 1.00 & \\
\hline IFS & 0.13 & .036 & 0.89 & .895 & 5.23 & .017 & 0.73 & .746 \\
\hline Municipal board & 0.18 & .012 & 1.01 & .986 & 2.74 & .075 & 1.60 & .530 \\
\hline \multicolumn{9}{|l|}{$\begin{array}{l}\text { Involved in } \\
\text { increasing resources } \\
\text { in : (ref=not involved) }\end{array}$} \\
\hline Eldercare & 2.61 & .081 & 1.20 & .738 & 0.82 & .655 & 1.13 & .849 \\
\hline Care of the disabled & 2.45 & .112 & 0.47 & .244 & 1.21 & .675 & 2.40 & .234 \\
\hline Social assistance & 0.43 & .483 & 10.43 & .003 & 1.16 & .807 & 5.60 & .016 \\
\hline Child/youth welfare & 1.44 & .569 & 1.41 & .581 & 3.54 & .008 & 5.21 & .054 \\
\hline $\begin{array}{l}\text { Measures for } \\
\text { substance abusers }\end{array}$ & 0.19 & .049 & 0.28 & .078 & 1.04 & .932 & 0.21 & .028 \\
\hline \multicolumn{9}{|l|}{$\begin{array}{l}\text { Involved in cutbacks } \\
\text { in: (ref=not involved) }\end{array}$} \\
\hline Eldercare & 0.48 & .153 & 0.44 & .147 & 2.58 & .033 & 1.95 & .250 \\
\hline Care of the disabled & 2.45 & .197 & 1.06 & .948 & 2.26 & .161 & 9.41 & .066 \\
\hline Social assistance & 0.46 & .372 & 2.99 & .106 & 0.50 & .210 & 0.93 & .928 \\
\hline Child/youth welfare & 0.81 & .824 & 0.16 & .053 & 0.78 & .688 & 0.39 & .274 \\
\hline $\begin{array}{l}\text { Measures for } \\
\text { substance abusers }\end{array}$ & 1.27 & .777 & 4.37 & .029 & 0.46 & .150 & 0.82 & .798 \\
\hline \multicolumn{9}{|l|}{ Allocative principle: } \\
\hline -of deservingness & 1.31 & .078 & 1.11 & .465 & 0.71 & .048 & 1.04 & .794 \\
\hline -of need & 1.09 & .513 & 1.05 & .673 & 0.91 & .366 & 0.99 & .923 \\
\hline -of economy & 0.98 & .939 & 0.87 & .341 & 1.06 & .594 & 1.12 & .514 \\
\hline -of capacity to benefit & 1.01 & .951 & 0.73 & .076 & 1.09 & .518 & 1.11 & .566 \\
\hline
\end{tabular}


Of the three variables capturing personal background, only gender established significant connections with the prioritized groups. Male politicians showed a higher inclination to see to the interests of the elderly, while females tended to support the unemployed to a higher extent. There are no obvious reasons why this pattern emerged. If anything, a more stereotypically gendered pattern would have suggested the opposite, with eldercare as a 'caring' and feminine arena and the labour market as a more masculine one; however, such an outcome was not present. Somewhat unanticipated also is the fact that politicians from the conservative block showed a tendency to advocate an increased focus on people with social problems. One reason for this may be that many answers within this category involve youth problems with respect to youth delinquency and that 'law and order' by tradition is a conservative key issue. A more expected outcome was found for different boards, where the area bias found in Table 4, which was most visible for the CED politicians, remains in the multivariate models here.

Among the municipalities, the politicians from Avesta stand out, with significant outcomes for two of the groups. Avesta was the only conservativegoverned municipality in the selection, and was selected owing to its having decreased resources in child welfare (see Table 1). In Table 8 we can see that children were given low support from Avesta politicians, which means that there is a certain match between attitudes and allocative trend in this municipality. This is, however, the only case where this kind of match can be identified. The politicians in Avesta also gave relatively low priority to social problems. This has no connection to any visible allocative trend, however. As we can see in the table, there were similar tendencies for Sollefteå and Borlänge.

In the models this study also used previous experience of increased and decreased resources as independent variables (as they were presented in Table 7, but with 'in general' and 'certain actions' merged together). A number of the significant relationships that were established here may be depicted as logical with respect to how previous decisions and attitudes go together. One example is that those involved in decisions on increased resources for social assistance also displayed an inclination to advocate priority for the unemployed and for people with social problems. A similar connection was found for child and youth welfare and children. The negative connection between increased resources in the area of substance abuse and priority to the elderly and the unemployed is less explicable, as are the outcomes for cutbacks.

Considering the allocative principles presented earlier, we can note here that the model displays rather frail relations. However, respondents in support of 'the principle of deservingness' are less in favour of prioritizing children and slightly more in favour of the elderly. Both of these client groups are by tradition the ones who receive the most support when professionals or political decision-makers are asked to pick a group to give priority to (Bergmark, 1995; Wörlén, 2010). The only other allocative principle establishing a relation is 'the principle of capacity to benefit', showing tendencies of being embraced by politicians who give less priority to people with 'social problems'. This group consists of clients with possibly less solvable problems and restricted opportunities to benefit from interventions. 


\section{Discussion}

How predictable, then, is the expressed priority-making of local political decision-makers? To what extent does information on personal background, political affiliation, area of responsibility, and so forth, tell us anything about their preferences and inclinations to support certain groups or activities? The general impression from the results presented here is that it is hard to detect clear-cut patterns of circumstances that guide the judgements in any one direction. The most noticeable exception to this is what is referred to above as area bias, that is, the tendency to prioritize clients and activities within one's own area of responsibility. This outcome is, of course, anything but unexpected. Nor is the fact that CED politicians seem to be the most visible representatives for such a bias, since the users within their domain are less heterogeneous compared to the wider array of client groups sorting under other boards.

To sum up, one might have expected more clear-cut divergences between the political blocks, considering the basis of party political ideologies and their positions. The results, however, show that political affiliation overall is not a determining factor. This confirms findings from previous research, where political issues and decisions on a local level have been shown to be more pragmatic and close to everyday life than is decision-making at the national level, or at least this seems to be the general outcome for prioritized groups. Yet in relation to allocative principles political colour seems to matter. Conservative politicians, as expected, agreed with the principles of economy and of capacity to benefit, while socialists, less expectedly, embrace the principle of deservingness. All these principles seem to be quite loosely connected to desired priorities, however. Accordingly, political affiliation seems to have an impact on more general beliefs but less on a micro-level, where different client groups are put up against each other.

The selection of municipalities for the study was based on recent allocative trends in different social-services sectors. An underlying assumption was that these trends should somehow correspond to expressed priorities. As actors within a local context, politicians can be expected to be either positive or negative to prevailing changes in resource distribution. The data in this study do not, however, support these kinds of relationships in any direction. In only one of the six municipalities did the allocative trend (decreased resources to child welfare) coincide with expressed priorities (a relatively low priority to children). Overall it seems that the decision-makers' opinions are only very weakly related (if at all) to local standards or local development.

Is the allocative profile created in a certain municipality, then, independent of basic values and political will? The nature of the data collected here does not allow any definite answer to that question. Resource allocation within local politics is a multifaceted activity where numerous interests are involved. In their capacity as those responsible for forming local policy the politicians have to be actively oriented towards professionals within the social-services organizations, local opinion, clients, and other stakeholders. This interaction may be more or less direct but overall it makes political decisions diffuse and rather hard to follow. In practice, local politics surpass the direct implementation of political programmes or compromises between political blocks. The views of the political decision-makers are normally intertwined with a layer of conflicting or alternative perspectives and the outcome of these processes are normally not easy to predict. 


\section{Acknowledgements}

The author gratefully acknowledges financial support from the Swedish Council for Working Life and Social Research: grant 2004-0401.

\section{Bibliography}

Aronsson, P. (1999). Lokala medborgarskap: det dolda kulturarvet? [Local citizenship: the hidden cultural heritage?] Stockholm: Fritzes.

Bergmark, A. (1995). Prioriteringar i socialtjänsten [Priorities in social services]. Stockholms Universitet, Stockholm.

Bergmark, A.. (1996). Need, allocation and justice: On priorities in the social services. Scandinavian Journal of Social Welfare, 5(1), 45-56.

Bergmark, $\AA$. (1997). From reforms to rationing? Current allocative trends in social services in Sweden. Scandinavian Journal of Social Welfare, 6(2), 74-81.

Björk, S., \& Rosén, P. (1993). Setting health priorities in Sweden: the politicians' point of view. Health Policy, 26(141-154).

Callahan, D. (1987). Setting limits. Medical goals in an ageing society. New York: Simon and Schuster.

Calltorp, J. (1989). Prioritering och bes/utsprocess i sjukvårdsfrågor: några drag i de senaste decenniernas svenska hälsopolitik [Priority-setting and the decisionmaking process in health care: some postwar characteristics of health policy in Sweden]. Uppsala: Univ.

Dierwechter, Y., \& Coffey, B. (2010). Assessing the effects of neighborhood councils on urban policy and development: The example of Tacoma, Washington. . The Social Science Journal, (47), 471-491.

Dworkin, R. (1981). What is equality? Philosophy and public affairs, 10, 283-345.

Elster, J. (1992). Local Justice. New York: Press Syndicate of the University of Cambridge.

Greener, I., \& Powell, J. (2003). Health Authorities, Priority-setting and Resource Allocation: A Study in Decision-making in New Labour's NHS. . Social Policy and Administration, 37(1), 35-48.

Ham, C. (1997). Priority setting in health care: learning from international experience. Health Policy, 42(1), 49-66.

Hasenfeldt, Y., \& Steinmetz, D. (1981). Client-official encounters in social services agencies. In G. T. Goodsell (Ed.), The public encounter. Where the state and citizen meet. Bloomington, Indiana: University Press.

Karski, R. L., \& Barth, R. P. (2000). Models of State Budget Allocation in Child Welfare Services. Administration in Social Work, 24(2), 45-66.

Lammintakanen, J., \& Kinnunen, J. (2004). Social and health-care priorities of local politicians in Finland: do the attitudes of politicians reflect the actual processes in municipalities? International Journal of Social Welfare, 13(1), 69-76.

Lewin, L. (Ed.). (2007). Democratic Accountability: why Choice is Both Possible and Necessary. Cambridge: Harvard University Press. 
Lien, S., \& Arnt Pettersen, P. (2004). Local Government and Welfare Generosity: Municipality Spending on Social Welfare. Scandinavian Political Studies, 27(4), 343-365.

Lister, R. (2010). Understanding Theories and Concepts in Social Policy. Bristol: Policy Press.

Martin, D. K., Giacomini, M., \& Singer, P. A. (2002). Fairness, accountability for reasonableness, and the views of priority-setting desicion-makers. Health Policy, 61(3), 279-290.

Reilly, D. H. (1994). Reflections of a 'Battered' Area Board Chairman (The Contest of Service Versus Politics). Community Mental Health Journal, 30(2), 105-117.

Taylor, B., \& Devine, T. (Eds.). (1994). Assessing needs and planning Care in Social Work. London: Collins Educational.

Temkin, L., S. (2003). Egalitarianism Defended. Ethics, 113(July), 764-782.

Thorslund, M., Bergmark, Å., \& Parker, M. G. (1997). Difficult decisions on care and services for elderly people: The dilemma of setting priorities in the welfare state. Scandinavian Journal of Social Welfare, 6(3), 197-206.

Trydegård, G.-B., \& Thorslund, M. (2001). Inequality in the Welfare State? Local Variation in Care of the Elderly - The Case of Sweden. International Journal of Social Welfare, 10(3), 174-184.

Wallentin, H. (1988). Värdiga och ovärdiga i socialpolitiken [The worthy and the unworthy in social policy]. In A. Ronnby (Ed.), Etik och Idéhistoria $i$ socialt arbete [Ethics and the history of ideas in social work]. Stockholm: Socionomen förlag.

Wörlén, M. (2010). Att prioritera i socialtjänsten - om kommunalt handlingsutrymme och beslutsfattande [Priorities in the social services. Autonomy in action and decision making in Swedish municipalities]. Socialvetenskaplig Tidskrift, 17(1) 28-45.

Wörlén, M., \& Bergmark, Å. (2011). Priorities and determinants of priorities of Swedish social workers. European Journal of Social Work. Published online 26 sept 2011, 0-19. 